\title{
The Woman School Principals' Leadership Facing the Educational Change in the Globalization Era
}

\author{
Kholifatul Husna Asri*, Kaniati Amalia, Muthahharah \\ Thahir \\ Educational Administration Studies Program \\ Universitas Pendidikan Indonesia \\ Bandung, Indonesia \\ *husnassri@upi.edu
}

\author{
Dedy Achmad Kurniady \\ Educational Administration Department \\ Universitas Pendidikan Indonesia \\ Bandung, Indonesia
}

\begin{abstract}
The purpose of this study was to find out the role of leaders in schools in facing educational changes in the era of globalization. All kinds of demands for student life are increasing, requiring qualified leaders who are brave in facing various problems and challenges in the world of education. This study used a descriptive qualitative design with study respondent was the principals. The finding of this study is that female school principals have the potential to lead show by the many advantages and achievements possessed in the schools. It can be concluded that the female principal is not only instructional, but act as a guide, transforming experiences, knowledge and skills of the school community.
\end{abstract}

Keywords-leadership, the principal challenge, educational change, globalization in education

\section{INTRODUCTION}

The change and innovation are important parts of human survival. However, the Change Process transformed into a modernization revolution throughout the world in the past. Generally, the globalization era and reformation has brought rapid changes to all fields in Indonesia and the world. So, if we do not increase the knowledge and capability, we will be far behind in everything [1].

The globalization era demands a revolutionary change in the national education system. This is needed to produce quality human resources, people who have intellectual capital who able to compete in the global competition. To produce the quality of human resources that must be done by improving the condition of education. Without education quality, there is little possibility of producing quality graduates. The role of the principal is very decisive, so she must be serious to utilize the information of technology for the advancement of education.

The main strategy to build a dignified people is through education. To achieve this, it is necessary to form the life view of the society that can lead them into a dignified people [2]. In addition, the Educational Institutions are also the process of forming human beings to be intelligent, moral, having a life motivation and a passion for developing science and technology [3]. According to the Legislation (Undang-Undang)
No. 20 of 2003 concerning the National Education System, Article 3, The aim of National Education is "Developing the potential of Students to become human beings who believe in and fear God Almighty, have good morality, be healthy, have knowledge, be creative, independent and become democratic citizens, and responsible.

Furthermore, the Legislation No. 22 of 1999 provides a freedom to the national education system, the concrete consequences of the Legislation are the realization of a new paradigm in the national education system, called as Educational Democratization. Through this new paradigm, the centralistic pattern changes to decentralization, and will impact on the policies to be taken. Certainly, that will be adapted to the current and future situation and condition of our country, especially in dealing with the effects of globalization.

Education in the globalization era is an effort to improve the integrity of life (life concepts and life values) in the technological era and information advancements as mentioned above called as globalization. Advances of technology and information in the globalization era are increased rapidly, make it easy for humans to find important information.

Education must be designed in a various way to enable students to develop their natural and creative potential in an atmosphere of freedom, togetherness and responsibility. Today, the student life demands are increasing. In the modern era like today, the advancement of education abandons a message of religious morality and culture of good character.

In this case, leaders in a school institution are expected to be able and brave to face various problems and challenges in facing the educational changes in the globalization era, and the qualified leaders are needed.

Every schools need leaders who have the spirit to become a leader, that is people who could influence, train, guide and they have the power to influence the others behaviour to follow their superiors or leaders so that cooperation is formed in groups to achieve organizational goals consciously, willingly, and wholeheartedly with a special leadership style. Leadership is a process of influencing and directing their members in their 
work that has been assigned to them [4]. Strong leadership and commitment in organizing the organizational programs is needed in every organizations.

In facing the world change of education, the role of leaders is very influential. Leaders must be able to create school output as a generation that has high competitiveness in global competition.

Principal need to have the capability that are suitable for children's education, so that children grow into healthy, intelligent individuals, fear to God Almighty and loving their country. Principal must be able to carry out the reforms of the educational process, with the pressure to create a more comprehensive and flexible education system. In addition, the principal must be able to manage the institutional aspects, curriculum, human resources, funding, and infrastructure.

The principal has many tasks that manage many educators, educational staff and students. As known that the principal has several tasks including influencing, encouraging, guiding and motivating teachers, staff, students, parents, students and stakeholders [5]. The school principal has a role as a drafter who carries out the preparation, implementation and follow-up of the school mission; as a manager that accommodates the interests of each group, instilling the good values that are used as a basis to realize the school vision [6].

In implementing educational goals in schools, leaders must be able to guide, determine policies and decisions, and have the science, so that school has a positive impact for the development and progress in the future and reach the goal properly and correctly based on established rules. Therefore, it can solve any problems and challenges, realizing the vision, mission and goals, and implemented optimally.

The role of women in leadership is not a strange thing. The term of gender equality is called the equality of the roles both men and women in obtaining their rights as humans. However, there are still some discrimination about women leadership [7].

Education for women has a lower priority than that for men. Likewise, workplaces are closed to women. the role of women is considered to remain at home taking the responsibility of caring for the children and home, whereas the responsibility of male member is to support the family financially [8]. These factors have caused an underrepresentation of women in leadership positions [9].

Based on this gap, in this study, the researcher tries to examine that female leaders are capable of becoming leaders in organizations, especially in educational institutions. Because, women leadership has extraordinary potential that can be utilized for educational progress. Educating the future generation as the first providers of education for their children, so that women need to have extensive insight and experience of information and communication technology in order to carry out their roles optimally. This will have an impact on creating the future generation to become an intelligent and has a conscience.
This study used a qualitative approach. So, the author can provide an overview related to leadership by using this study method. The interviews, published data, documents and observations are used as an instrument for this study. And the study took a place at 70 State Senior High School Jakarta.

\section{BACKGROUND}

\section{A. Woman's Leadership}

According to Mullins, "Leadership is a relationship through which one person influences the behaviour actions of other people". This definition emphasizes the concept of "relationships" which a person influences the behaviour or actions of others. In this definition, leadership can apply in formal or informal organizations. If a group is formed, then the leadership is present to guide the group [10].

Leadership is an activity of structuring ability to influence the others behaviour in certain situations in order to build a team work to achieve predetermined goals. There are many ways to influence others, such as showing an example of future, giving orders, giving rewards, delegating authority, trusting members, etc.

To influence others, we can show an example of future, giving orders, delegating authority, trusting members, giving rewards, giving tasks, giving responsibilities, giving opportunities to represent our duty, persuading, asking for advice, opinions, and consideration, giving the opportunity to lead others, fulfilling desires, motivating, defending, educating, guiding, pioneering, kindling, encouraging discipline, setting an example, expressing new ideas, giving direction, giving confidence, encouraging, create change, threaten, give punishment, and others

In the current development, women have emerged as leaders, so that women have additional duties besides being a housewife, they also have a duty to be a leader.

According to Doyle, gender is a concept that is used to describe the differences between men and women in social culture. The difference refers to the emotional and psychological elements, as social characteristics of the relationship between men and women is constructed. So that it differs between place and time, for example women are known as graceful, beautiful, emotional and motherly creatures while men are considered strong, rational, and mighty [11].

Porter examines about linking gender issues and leadership styles with two aspects of leadership, (1) in making decision, oriented to democratic or autocratic leaders and (2) influencing members, superiors, and colleagues with communication strategies [12].

Basically, women have the basic traits to be a success leader. They have patient, empathy, and multitasking so that they can do several things at once. Women also have a talent for networking and negotiating. 
Women's leadership tries to explain what is owned by a woman in their leadership. According to Kanter, there are four factors that influence women's leadership, (1) Mother, a woman sometimes being a mother in a group or organization while she leads in the forum. Assumed that women are sympathetic, good listeners and a nice friend to share personal matters. (2) Pet, the pet adopted by employees as things that can entertain to show greatness in women's leadership. (3) Iron maiden is a change in the present, the role in which strong women are placed. It is different from the others women's roles. The iron maiden is shown by a women leader with a style of competence that is owned in a straightforward manner and wants to position their self as equal to anyone. Leaders with the role of iron maiden is known as a tough and trapped in militant attitude than others [13].

\section{B. Globalization Era Education}

Education is one of the most important things to prepare competitive human resources to achieve a success in the globalization era. Education is the main pillar for the progress of a nation [14-17]. Based on this statement, education must become a priority for development, without ignoring other sectors.

Education has an important role in dealing with changes in today era. Education will provide directions to respond a change. Change will be passed well and used as a foundation in realizing full community development if education becomes the main pillar in that change. Therefore, education can be a transformation tool, and need proper attention to education than other fields, because the others will develop by themselves when the education was better. However, the fact that education in Indonesia is factually still lag from other countries [18].

Developing the education is not only by changing the curriculum and completing facilities and infrastructure, but also pay attention to the development of Human Resources (HR) that will carry out the education. Therefore, to achieve better education in the future, the main priority is improving human resources (HR) through quality education and evenly distributed to all society, and most importantly is to raise awareness for each element of society and the government and the parties concerned to improve themselves [19].

In the globalization era is education is needed to relate a five competencies, (1) intellectual competence, that have the ability to think, be creative, solve the problem, and the ability to take strategic decisions (2) personal competence, that have nobleness of soul and good morals, in the form of honesty, discipline, independence, critical and responsible, (3) communicative competence, means that having language and communication skills with others, (4) socio-cultural competence, is the ability to live together and cooperate with others and (5) vocational kinesthetic competence, is the ability to use science and technology to support the progress of global life [20].
The education system should develop the students' skills and desire to learn throughout life, preparing them for a career, and create the ability to make decisions.

Global education can be assessed through two perspectives. Curricular perspective, curricular perspective is an educational process that aims to prepare educated personnel to have the ability of individuals to understand life of world community, with characteristics; 1) Studying culture, understanding interdependence. 2) Studying various branches of science to be used in accordance with local environmental needs. 3) Developing various abilities to work together to create a better world community life [21].

\section{RESULTS}

The principal's leadership determines various rules and policies for all school members [22]. Being a professional school principal is required to have various competencies, as stipulated in the Minister of National Education Regulation No. 13 of 2007 concerning Principal Standards, that the principal has competencies of personality, supervision, managerial, entrepreneurship, and social competence. Furthermore, it is supported by the opinion of Muhyadi in his study that a leader must have intelligence, maturity and discretion in social relations, have self-motivation and reach achievement and have attitudes towards human relations [23].

To manage the school, strategies are needed to increase the knowledge of the school members in responding to the globalization. Students are expected to compete along with the development of globalization. Advances of technology and science have their own impact on the world of education. As same as the opinion expressed by Fengerlind and Saha in Syaiful Sagala that education has an important role in increasing the skills and abilities of the workforce. This must be supported by the character of human resources as human capital and modernization, means that the community can increase productivity through education to sustain the economy with modern industry as a strategic development goal [24].

The results of study show that school principal realizes that education has an important role in preparing the future of students, which has a different change every time. The current of globalization has spread to all life aspects that cannot be avoided. School leadership in societies offers several challenges especially for women.

Women's leadership in 70 State Senior High School Jakarta is considered to manage schools and face the changes of educational environment, leaders are strategic positions for the women. Leading is not only a profession that requires willingness, but also must have ability. Ability is a leadership's skills in managing the tasks, proven by changes or new actions that occur due to good school management. The human resources (HR) owned by 70 State Senior High School Jakarta has good competence and expertise, a supportive infrastructure, comfortable, clean and beautiful school environment, colorfull school walls and a friendly impression for students and teachers. All of that are evidence that the women's leadership 
at 70 State Senior High School Jakarta could make changes. The women school as powerful role models for students and teachers, be an inspiration and able have beneficial effect $[25,26]$.

The leadership of the woman principal is responsible for carrying out her role for the success of the school and has the courage to make decisions and act with consideration. It can be seen how the school principal is able to compile school programs and monitor student achievement. The principal engages the students' parents in school activities through human relationships that are created and responds to community expectations relating to student discipline outside of school. So, the women principal must be able to do social interaction, social skills, and ability to work in groups [27].

Shakeshaft stated that women as principals devote more time with teachers, administrative staff and students, care about individual differences, knowing and motivating them [28] Morever, the women principal can able an effective mentor, influencing their career advancement and retentions at job place [29-31].

The role of the woman principal as an educator, naturally attached to her, for example she must give birth, nurture, guide, set an example and educate. This continues to be socialized evolutionarily and slowly influences the development of emotions, visions, motivating others and are considerate of individual differences and ideologies of woman principals in performing their role as educators. Further, the women as leaders are pay more attention to collaboration, caring, empathy is not dominant and respect for everyone. As stated by Robinson, the characteristics of leadership effectiveness are persuasive and not dominant [32-34].

The women show many advantages in the position of school administrator compared to men [35]. Furthermore, women are more careful, wise and more collegial than men and women are quicker to make decisions [36].

As seen at 70 State Senior High School Jakarta, the principal provides opportunities for subordinates/members to participate, such as involving involvement in the formulation of the vision, mission and goals of the school; formulating school programs, developing learning, making teaching aids and appropriate teaching materials, developing students' interests and providing technical guidance to students. In addition, the teacher always involved in non-academic decision making which includes conduct an extracurricular, social activities, build relationships with parents / community, build student character and make school discipline rules. This is a form of appreciation for the teacher, which has an impact on improving the quality of the teacher.

Facing the educational changes in the globalization era, the woman principal of 70 State Senior High School Jakarta has superior characteristics and shows adaptive behavior to change, she able to capture the phenomena in her leadership environment and understand her follower. According to the principal, the current global situation needs to create a more comprehensive and flexible education system, so the graduates can function effectively in the lives of the global community. Therefore, principals at 70 State Senior High School Jakarta design the best education systems to develop their natural and creative potential in an atmosphere of freedom, togetherness and responsibility.

The educational change helps the learning process and can improve performance outcomes. However, the change of globalization era is a challenge for the principal's leadership, that the dynamics of complex quality competition. The leaders must be visionaries who can produce a variety of policies and operationalize the work of school residents based on a clear vision, enthusiasm and dedication of work to achieve the educational goals of 70 State Senior High School Jakarta that they lead. The existence of a clear vision of education carried out consistently by educational leaders must be supported by cultural changes that are more oriented to the quality of the process and the results of education. Therefore, the important thing as a broad-minded educational leader to achieve the quality of education in the globalization era is that have a strong influence on the effectiveness of educational attainment [37-39].

\section{CONCLUSION}

Facing the educational changes in the globalization era and the complexity of the development of the education world. The leadership role of woman principals at 70 State Senior High School Jakarta is not only instructional, but the principal acts as a guide and introduce the change or transform the experience, knowledge and skills of the school community. That because she can portray and create organizational effectiveness, such as the realization of school achievements, the creation of kinship relationships and can empower her members and emphasize teamwork of organizational structure, trusted, flexibility and willingness to share information.

\section{ACKNOWLEDGMENT}

I am enormously grateful to my supervisor and professor, for warm support, inspiration and thoughtful guidance.

\section{REFERENCES}

[1] R. Buhungo, "Wanita dan Kepemimpinan Dalam Pendidikan Islam di Era Kehidupan Modern,” Jurnal Manajemen Pendidikan Islam, Vol. 5, 2017.

[2] E. Dewi, "Potret Pendidikan di Era Globalisasi," Jurnal Pendidikan, Vol. 3, No. 1, pp. 91-116, 2019.

[3] H. Indra, Pendidikan Islam Melawan Globalisasi. Jakarta: Ridamulia, 2005 .

[4] E. Sule, dan Saefullah, Pengantar Manajemen. Jakarta: Kencana Prenada Media, 2008.

[5] Murniati, Manajemen Sratejik; Peran Kepala Sekolah Dalam Pemberdayaan. Bandung: Citapustaka Media Perintis, 2008.

[6] Jelantik, Menjadi Kepala Sekolah yang Profesional. Yogyakarta. Deepublish. 2012 
[7] A.H. Makura, The Challenges Faced by Women School Heads: The Zimbabwean Experience. Retrieved from http://www.emasa.co.za/files/emasa2009/13_EMASA,2009_Makura.pdf

[8] E. Lahti, Women and Leadership: Factors that Influence Women's Career Success: Female Leaders' Reflections on Their Career Development and Leadership, 2013.

[9] Jane. S. Shalom, A. Bessie, K., and W. Daisy, "You Have Been A Servant To All: Melanesian Women's Educational Leadership Experiences," School Leadership and Management, Vol. 30, No. 1, pp. 65-76, 2010.

[10] M.J. Laurie. Management and Organizational Behavior. 7th Edition. Essex: Pearson Education Limited, 2005.

[11] J.A. Doyle, Sex and Gender; The Human Experience. Iowa: Brown Publisher, 1985.

[12] L.W. Porter, W.J. Crampon and F.J. Smith, "Organizational Commitment and Managerial Turnover," Organizational Behavior and Human Performance, Vol. 15, pp. 87-98, 2004.

[13] M.S. Kanter, Men and Women of the Corporation. New York: Collin Publisher, 1976

[14] G. Soutworth, "Instructional Leadership in School: Reflection and Empirical Evidence," School Leadership and Management, Vol. 22, No. 1, pp. 73-92, 2002.

[15] K.G. Shockley, "Africentric Education Leadership: Theory and Practice," International Journal of Education Policy and Leadership, Vol. 3, No. 3, 2008.

[16] A.R. Briggss, J. Clark, and I. Hall, "Building Bridges: Understanding Student Transition to University," Quality in Higher Education, Vol. 18, No. 1, pp. 3-21, 2012.

[17] J.L. Menzies and K. Baron, "International Postgraduate Student Transition Experiences: The Importance of Student Societies and Friends," Innovations in Education and Teaching International, Vol. 51, No. 1, pp. 84-94, 2014.

[18] A. Rinawati, "Transformasi Pendidikan Untuk Menghadapi Globalisasi," Jurnal Pendidikan Ekonomi, Vol. 3, No. 1, 2015.

[19] Hermino, Kepemimpinan Pendidikan di Era Globalisasi. Yogyakarta: Pustaka Pelajar, 2014

[20] Istiarsono, "Tantangan Pendidikan dalam Era Globalisasi. Kajian Teoritik," Jurnal Intelegensia, Vol. 1, No. 2, 2016.

[21] A. Idrus, Manajemen Pendidikan Global Visi, Aksi \& Adaptasi. Jakarta: Gaung Persada Press, 2009.

[22] Mulyasa, Menjadi Kepala Sekolah Profesional. Bandung; Rosdakarya, 2009.

[23] E.I, Kristiyanti and Muhyadi, "Kepemimpinan Kepala Sekolah Perempuan," Jurnal Akuntabilitas Manajemen Pendidikan, Vol. 3, No. 1, pp. 37-49, 2015 .
[24] S. Sagala, Manajemen Berbasis Sekolah dan Masyarakat (Strateg Memenangkan Persaingan Mutu). Jakarta: PT Nimas Multima, 2004.

[25] I.M. Latu, M.S. Mast, D. Bombari, J. Lammers and C.L. Hoyt, "Empowering Mimicry: Female Leader Role Models Empower Women in Leadership Tasks Through Body Posture Mimicry," Sex Roles, Vol. 80, No. 1-2, pp. 11-24, 2018.

[26] S. Khalid, M. Rehman, F. Muqadas and S. Rehman, Mentoring Role Towards Career Development, Women Leadership and Its Mentoring, Superior University, Lahore, Pakistan, 2017.

[27] E. Lahti, Women and Leadership: Factors that Influence Women's Career Success: Female Leaders' Reflections on Their Career Development And Leadership, 2013.

[28] C. Shakehaft, Women in Educational Management in the United States. New York: Sunny, 1994.

[29] R.M. Kanter, "Some Effects of Proportions on Group Life: Skewed Sex Ratios and Responses to Token Women," American Journal of Sociology, pp. 965-990, 1977

[30] R.A. Noe, "Women and Mentoring: A Review and Research Agenda," Academy of management Review, Vol. 13, No. 1, pp. 65-78, 1998.

[31] H. Ibarra, "Personal Networks of Women and Minorities in Management: A Conceptual Framework," Academy of Management Review, Vol. 18, No. 1, pp. 56-87, 1993

[32] C. Robbins, Leading Effectively Leadership Can Be Taught but Commitment Needed, 2001

[33] L. Cubillo and M. Brown, "Women in Educational Leadership and Management: International Differences?," Journal of Educational Administration, Vol. 41, No. 3, pp. 278-291, 2003.

[34] N. Mythili, "Quest for Success: Ladder of School Leadership of Women in India," Social Change, Vol. 49, No. 1, pp. 114-131, 2019.

[35] R.G. Owens, Organizational Behavior in Education. Englewood Cliffs, New Jersey: Prentice-Hall. Inc, 1991.

[36] S. Adler and J. Laney, Managing Women. Buckingham: Open University Press, 1993.

[37] J.H. Berg, C.L. Carver and M.M. Mangin, "Teacher Leader Mode Standards: Implications for Preparation, Policy, and Practice," Journal of Research on Leadership Education, Vol. 9, No. 2, pp. 195-217, 2014.

[38] E.D. Severson and J.B. DeStefano, "Leadership for Transformational Learning: A Developmental Approach to Supporting Leaders' Thinking and Practice," Journal of Research on Leadership Education, Vol. 9, No. 2, pp. 113-141, 2014.

[39] K.K. Hewitt, A.W. Davis, and C. Lashley, "Transformational and Transformative Leadership in a Research-Informed Leadership Preparation Program," Journal of Research on Leadership Education, vol. 9 , pp. 225-253, 2014 